\title{
Modeling Virtual Ecosystems that Consist of Artificial Organisms and Their Environment
}

\author{
Sang-Hee Lee* \\ Division of Fusion Convergence of Mathematical Sciences, National Institute \\ for Mathematical Sciences, Daejeon 305-340, Korea \\ (Received June 15, 2010; Revised June 26, 2010; Accepted June 28, 2010)

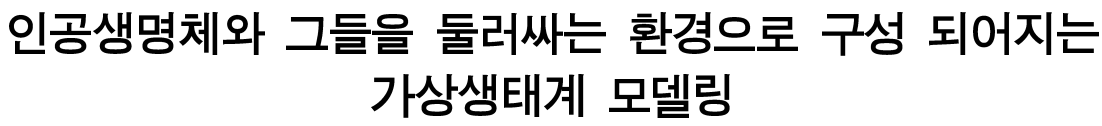

이 상 희*

국가수리과학연구소 융복합수리과학부

(2010년 6월 15일 접수; 2010년 6월 26일 수정; 2010년 6월 28일 수락)

\begin{abstract}
This paper introduces the concept of a virtual ecosystem and reports the following three mathematical approaches that could be widely used to construct such an ecosystem, along with examples: (1) a molecular dynamics simulation approach for animal flocking behavior, (2) a stochastic lattice model approach for termite colony behavior, and (3) a rule-based cellular automata approach for biofilm growth. The ecosystem considered in this study consists of artificial organisms and their environment. Each organism in the ecosystem is an agent that interacts autonomously with the dynamic environment, including the other organisms within it. The three types of model were successful to account for each corresponding ecosystem. In order to accurately mimic a natural ecosystem, a virtual ecosystem needs to take many ecological variables into account. However, doing so is likely to introduce excess complexity and nonlinearity in the analysis of the virtual ecosystem's dynamics. Nonetheless, the development of a virtual ecosystem is important, because it can provide possible explanations for various phenomena such as environmental disturbances and disasters, and can also give insights into ecological functions from an individual to a community level from a synthetic viewpoint. As an example of how lower and higher levels in an ecosystem can be connected, this paper also briefly discusses the application of the second model to the simulation of a termite ecosystem and the influence of climate change on the termite ecosystem.
\end{abstract}

Key words : Virtual ecosystem, Artificial organism, Agent-based model, Climate change

\section{INTRODUCTION}

An ecosystem is a dynamic complex of plants, animals, microorganisms, and nonliving organisms in the environment, all interacting as a single functional unit. All ecological factors are directly or indirectly linked to and influence one another. Thus, any disturbance to a single element in an ecosystem can cause a damage in various extent to the overall system. For example, the build-up of carbon dioxide in the atmosphere resulted in global warming, which in turn led to a decrease in the global krill biomass (Baes et al., 1977; Emanuel et al., 1980; Gardner et al., 1980; Schlamadinger et al., 1995). In the next century, krill biomass is expected to

* Corresponding Author: Sang-Hee Lee (sunchaos@nims.re.kr) 
decrease by $95 \%$ throughout the Scotia Sea (Murphy et al., 2007). Since krill is a key component of the Southern Ocean food chain, its decrease threatens to destabilize the entire aquatic ecosystem (Schmidt et al., 2003). The climate change has both positive and negative impacts on sustainable agriculture of a country, where sustainable agriculture affect agricultural productivity, food security, technology, and environment which have different components, with varying priorities in global and regional levels (Adams et al., 1990; Kane et al., 1992).

Theoretical biologists and ecologists have attempted to develop ecological models to account for the relationship between such ecological variables and the stability of an ecosystem. These models have helped us to better understand the major dynamics of ecosystems and to predict their behavior (in general terms, or in response to particular changes). Most ecosystem models, however, have had a limited capacity to reflect actual ecosystems synthetically because they are too simplified and localized due to the extreme difficulty of quantifying ecological factors, excessive computational costs, and uncertainties associated with obscure elements (Hurtt and Pacala, 1995).

The recent increase in less expensive computational power now enables us to successfully overcome these problems by considering many more factors that characterize actual ecosystems in multiple hierarchical levels, from that of an individual element to an entire population. Such an individual-based model that can deal with multiple levels is known as a virtual ecosystem (Peacor et al., 2007). To construct a virtual ecosystem, various approaches must be adopted in order to efficiently reduce the huge computational cost of running an algorithm on that ecosystem.

The present study introduces three main approaches along with examples, which could be used to build a virtual ecosystem: (1) a molecular dynamics simulation approach for animal flocking behavior (Lee et al., 2006), (2) a stochastic lattice model approach for termite territorial behavior (Lee et al., 2007), and (3) a rule-based cellular automata approach for biofilm growth (Lee et al., 2004). With an example of the application of the termite territory model to the challenge of climate change, we briefly described how a virtual termite ecosystem responds to such change. The purpose of this study is to introduce the concept of a virtual ecosystem and show how the virtual ecosystem can be linked to real corresponding system.

\section{MATHEMATICAL APPROACHES TO A VIRTUAL ECOSYSTEM}

\subsection{Molecular dynamics simulation approach for flocking model}

The unique behavior of a large number of dynamic interacting individuals, known as "flocking", has attracted many researchers from diverse fields of scientific and engineering disciplines (Desai et al., 2002). In the field, flocking behavior is frequently observed in animal populations and is often maintained with no apparent supervisors and no external stimuli (Videler, 1993). Well-known examples are found in prey populations such as large schools of fish (Huth and Wissel, 1994) or gatherings of birds (Maldonado-Coelho and Marini, 2004). Several hypotheses have been proposed for the reasons behind this aggregation of organisms: reduced risk of capture by predators, higher mating efficiency, easier search for food, efficient learning of external stimuli, and reduced overall aggression (Cashing and Harden-Jones, 1968; Zheng et al.,2005; Viscido et al., 2001; Parrish et al., 2002; Adioui et al., 2003).

This flocking behavior can be simulated by the application of the following three rules (Reynolds, 1987): (1) maintain a certain minimum distance between nearby individuals, (2) steer them in the approximate direction toward which the rest of the individuals are heading, and (3) move individuals toward the average position of all the individuals nearby.

These three rules can be written in Newton's second law (Lee et al., JTB, 2006; Lee, 2007) as follows:

$$
m_{i} d_{t} \vec{v}_{i}=\vec{f}_{i}^{\text {align }}+\vec{f}_{i}^{\text {att }}-\vec{f}_{i} \text { rep } \vec{f}_{i}^{\text {fric }}, \vec{d}_{t} \vec{x}_{i}=\vec{v}_{i}
$$

where $m_{i}, x_{i}$, and $v_{i}$ are respectively the mass, position, and velocity of the $i$-th individual. $f_{i}^{q}(q=$ align, att, rep, and fric) represents various forces that represent the interactive behavior among individuals (align: alignment, att: attraction, rep: repulsion, and fric: friction).

The force of alignment was given as

$$
\vec{f}_{i}^{\text {align }}=\sum_{j(i \neq j)} \frac{g}{\left|\overrightarrow{x_{i}-\vec{x}_{j}}\right|} \hat{v}_{j}
$$

where $x_{i}$ and $x_{j}$ indicate the $i$-th and the $j$-th individual position, $\hat{v}_{j}=v_{j} \backslash v_{j} \mid, v_{j}$ is the velocity of the $j$-th individual, and $g$ is the strength of the force of alignment. The $g$ contributes to making each member of the flock to move in the same direction. The value of $g$ was set appropriately at 0.5 .

The force of attraction between individuals was 
described as a decreasing exponential function. When the $i$-th individual was located in the attractive field of the $j$-th individual, the $i$-th individual was assumed to move towards the $j$-th individual. The force of attraction was described as below:

$$
\vec{f}_{i}^{a t t}=c_{a t t} \sum_{i \neq j} \exp \left(-\left|\vec{x}_{i}-\vec{x}_{j}\right| / l_{a t t}\right) \hat{f}_{i, j}^{a t t}
$$

where $\vec{f}_{i}^{a t t}=\left(\vec{x}_{j}-\vec{x}_{i}\right)\left|\vec{x}_{j}-\vec{x}_{i}\right|$, and $c_{a t t}$ is a constant. The strength of the force of attraction was characterized by a length scale $l_{\text {att }}$ in a decreasing exponential function.

The force of repulsion between individuals was additionally expressed by a decreasing exponential function. When the $i$-th individual was in the field of repulsion of the $j$-th individual, the $i$-th individual moved away from the $j$-th individual to avoid a collision, depending upon the distance between the two individuals. The force of repulsion was described as follows:

$$
\vec{f}_{i}^{\text {rep }}=c_{r e p} \sum_{i \neq j} \exp \left(-\left|\overrightarrow{x_{i}}-\overrightarrow{x_{j}}\right| / l_{\text {rep }}\right) f_{i, j}^{f_{i, j}}
$$

where $\vec{f}_{i, j}^{r e p}=\vec{x}_{i}-\vec{x}_{j}\left|\overrightarrow{x_{i}}-\overrightarrow{x_{j}}\right|$ and $C_{\text {rep }}$ is a constant. Simi- lar to the case of attraction, $l_{\text {rep }}$ was used to characterize forces that repel one another.

To prevent individuals from moving too quickly, the friction force with coefficient $\tilde{a}$ was set to be proportional to the current speed of an individual:

$$
\vec{f}_{i}^{\text {fric }}=\overrightarrow{j w}_{i}
$$

When we introduced 200 particles (individuals) into two-dimensional space, the individuals flocked together as time passed in accordance with the three forces (see Fig. 1).

2.2. Stochastic lattice model approach to termite territory model

Subterranean termites usually tunnel underground to do their foraging. Their tunnel galleries reach lengths ranging from tens to hundreds of meters long (King and Spink, 1975). These tunnel galleries determine their territory. Thus, the size and shape of a given territory reflects a compromise between the foraging efficiency of the termite colony and other biological and/or ecological constraints, such as the number of active foragers, soil hardness, and food availability (Lee and $\mathrm{Su}$,

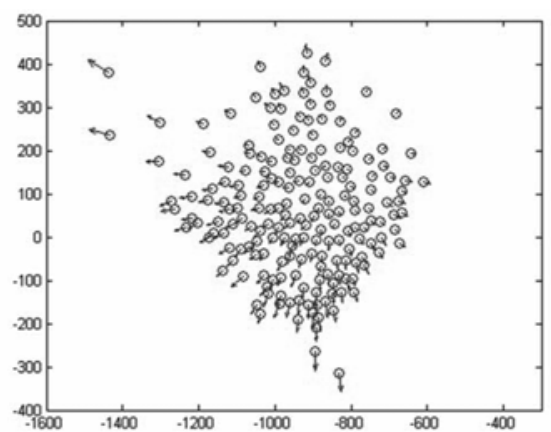

(b) $\mathrm{t}=100$
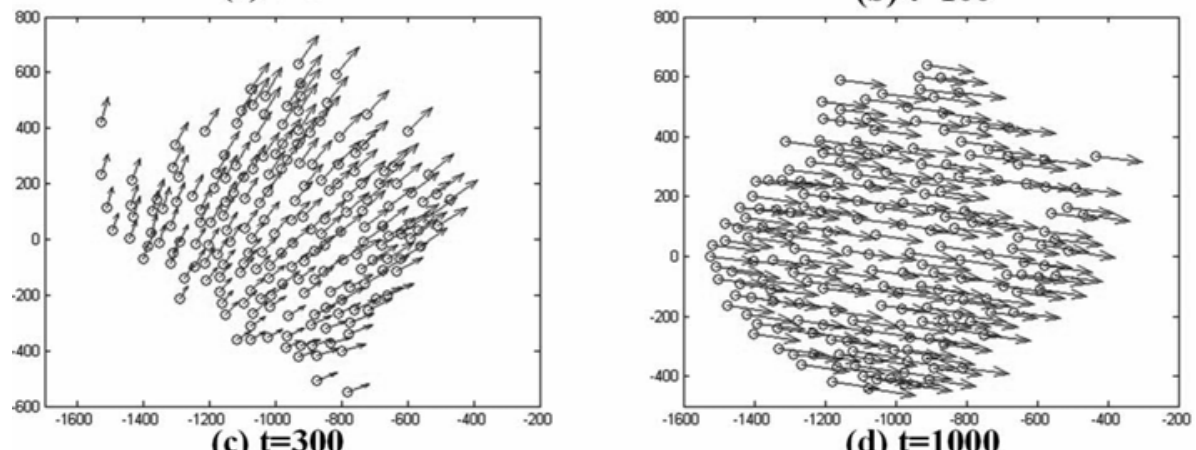

(d) $\mathrm{t}=1000$

Fig. 1. Photographs showing the process of alignment of individuals in a flock. The arrows attached to the circles indicate velocity. 
2009a). Thus, an understanding of territorial behavior is essential to our understanding of how a termite colony is organized and its efficiency at foraging.

A stochastic lattice model approach was adopted for the simulation of termite territorial behavior because this model has been recognized as a powerful approach to the investigation of the effect of neighborhood interactions on the dynamics of not only plants and forests, but also of animal and human societies (Nakamaru, 2006).

Termite territory was simulated on a two-dimensional lattice space composed of cells of dimensions $L \times L$, where $L(=200)$ is the system size. Each cell was in one of three possible states: occupied by active termites (active termite cell), occupied by inactive termites (inactive termite cell), or empty (empty cell).

In the model, the landscape was produced by allotting randomly generated values, ranging from 0.0 to 1.0 , to each cell. These values represented the degree of ease in the construction of tunnels. Higher values corresponded to soil conditions that are conducive to easier tunneling. Thus, this value can be interpreted as the transition probability, $P_{\text {trans }}$, that an active termite cell will grow into its neighboring cell. When an active termite cell is surrounded by cells with low value of $P_{\text {trans }}$, the active termite cell might stop growing and become an inactive termite cell. In field, the inactive termite cell can be corresponded to termite tunnel tip that encounters adverse environmental condition such as soil with very high moisture and rocks.

The model also incorporates the seasonal cycles of summer and winter. For the sake of theoretical simplification, it was assumed that the seasons change according to a step function with two time scales: summer time and winter time. The simulated territory grew in the summer and shrank in the winter. In order to fit the time scale, the experimental data were compared to those reported by Bess (1970) and Li et al. (1979) in the simulation; it was found that an iteration time of $T$ $=36$ corresponds to the duration of summer in New Orleans, Louisiana (Lee et al., 2007). Because there was no interplay among cells, which would have required a time of interaction, the processes in the winter season were fulfilled in one iteration time $(T=1)$. At the beginning of the simulation run, $N$ active termite cells, which represented the number of founding pairs, were randomly introduced into the lattice space.

The rules that determine the cell growth from one generation to the next in the framework of the territory dynamics were as follows:

\subsubsection{Rules of growth and cell-cell interaction (summer season)}

- When an active termite cell met an empty cell with a higher $P_{\text {trans }}$ value, the active termite cell could grow into the empty cell more easily than it could into a cell with a lower $P_{\text {trans }}$ value (Fig. 2(a)). In this figure, the most active termite cells had the highest probability of growing into the top right site.

-When two active termite cells met, they could not share the same site (Fig. 2(b)).

-When more than one active termite cell competed with another for occupation of an empty site, the occupant of the site was determined by a coin toss (Fig. 2(c)).
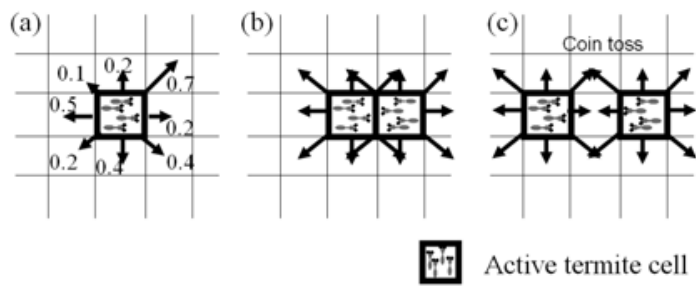

Active termite cell

Fig. 2. Possible configurations in which each active termite cell can encounter an obstacle or another active termite cell. The arrows indicate the direction of growth of each active termite cell. A solid circle represents an obstacle. A square with termites is an active termite cell.

(a)

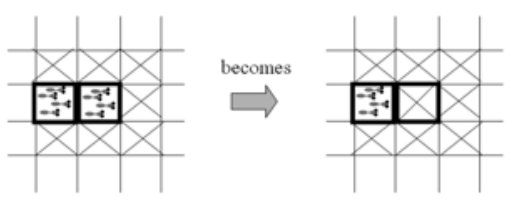

(b)

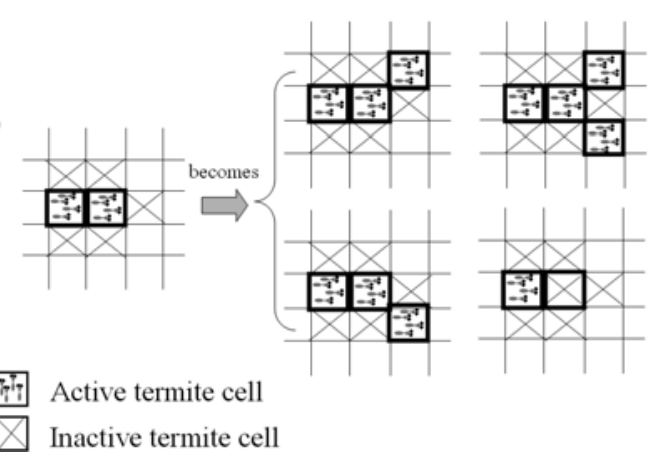

Fig. 3. Multiplication process (state-changing rule) of each active termite cell (a) surrounded by 7 obstacle cells, or (b) towards one of its unoccupied next-neighbor sites during one discrete time step $t \rightarrow t+1$. 
2.2.2. Rules of State-Change (from an active termite cell to an inactive termite cell)

-When a single active termite cell was surrounded by 7 inactive cells, the active termite cell was changed to an inactive termite cell (Fig. 3(a)).

- When a single active termite cell was surrounded by less than 7 inactive cells, the termite cell could either grow into the empty cells or stop probabilistically. Once it stopped, it was changed into an inactive termite cell (Fig. 3(b)).

\subsubsection{Rules of Shrinkage (winter season)}

- Messenger and Su (2005) reported that C. formosanus colony territories contracted almost $80 \%$ during the winter, as compared to the summer. Based on this observation, active/inactive termite cells were removed according to distance, with the cells furthest from the seed cell removed first, until about $80 \%$ of the cells remained (Fig. 4(a)).

- After the territory size shrank, several of the (a)

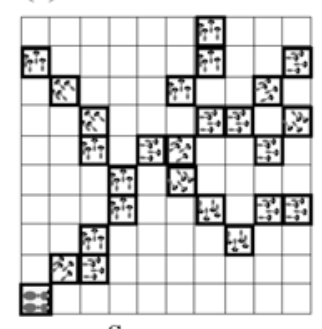

Summer

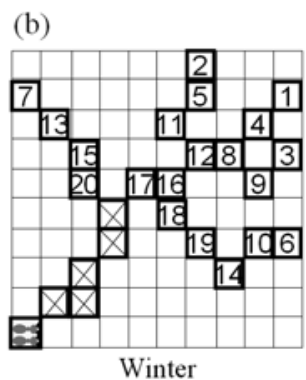

Winter
Seed cell

Inactive termite cell

Fig. 4. Process of territory shrinkage during winter season: (a) territory size decreases to $\sim 80 \%$. Termite cells are sequentially removed according to the rule, "the furthest cells are removed first" (b) after shrinkage, new active termite cells are chosen to provoke territory growth. remaining inactivated cells were chosen by a probability function on the basis of their distance from the seed cell; these inactivated cells were changed into active termite cells to initiate territorial growth (Fig. 4(b)). The preferential weighting of distant cells as starting sites for new tunnel growth stems from the assumption that growth is most likely at the colony's periphery.

Fig. 5 shows the typical patterns of a simulated termite territory at a steady state, which was reached after a sufficiently long time $(\mathrm{t}=20)$. The color white represents termite cells and territory, and black indicates empty space. Territorial competition problems were dealt by Lee et al (2009b).

\subsection{Rule-based cellular automata approach for biofilm model}

Biofilms are microbial assemblages that occupy a spatial interface by creating a chemically distinct microenvironment. Biofilms can be readily established at any interface of a living organism (e.g., dental plaque on teeth), non-living organisms (e.g., soil, rocks in riverbeds, marine and freshwater sediment, etc.), and non-natural products (e.g., filters, ship hulls, pipelines, bioreactors, etc.) (Stoodley et al., 1997).

Each bacterium grows and dies according to its surrounding condition. These kinds of organisms can be easily described using a cellular automata (CA) approach. Cellular automata are the simplest models of spatially distributed processes. They consist of an array of cells, each of which is allowed to be in one or in several states. At the same time, each cell looks to its neighbors to see what states they are in. Using the information received, each cell applies a simple rule to determine what state it should change to. Following Lee et al. (2004), a biofilm model consisting of two bacterial species - toxin-sensitive and toxin-producing bacteria - was constructed.
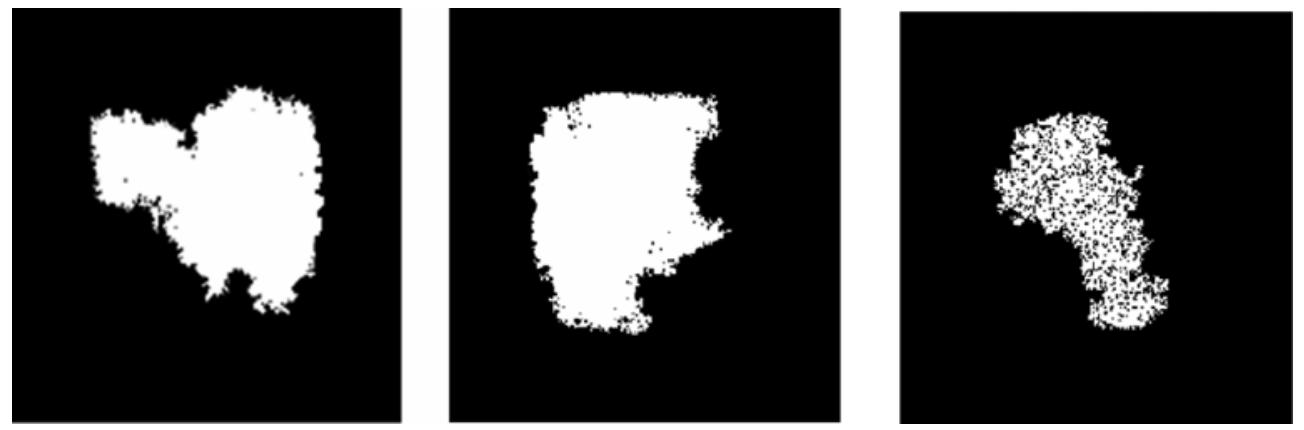

Fig. 5. Typical territory patterns formed at steady state, which are reached after a sufficiently long time $(t=20)$. 


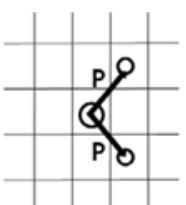

(a)

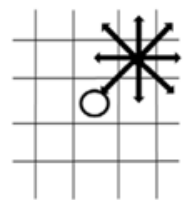

(f)

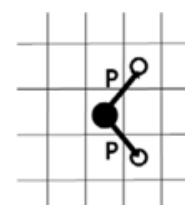

(b)

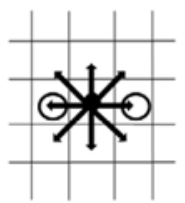

(g)

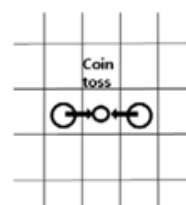

(c)

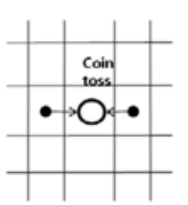

(h)

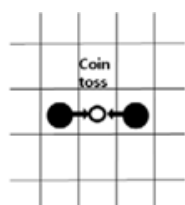

(d)

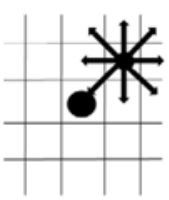

(i)

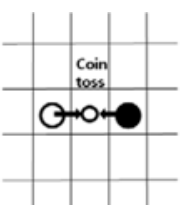

(e)

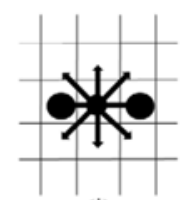

(j)

$\begin{array}{lll}\text { Toxin-producing bacteria } & \text { Toxicant } \\ \text { Toxin-sensitive bacteria } & 0 & \text { Nutrient }\end{array}$

Fig. 6. All possible configurations in which each bacterial organism encounters a toxicant or a nutrient. The arrows indicate either the direction of growth of each specimen or the direction of movement of each nutrient and toxicant. The large solid octagon, large octagon, small solid octagon, and small octagon represent toxin-producing specimens, toxin-sensitive specimens, toxicants, and nutrients, respectively.

The model was described in a two-dimensional system with an $L \times L(L=200)$ site grid, where $L$ is the system size. Updating is carried out synchronously for individual organisms of bacteria, nutrients, and toxicants. Each bacterial organism, nutrient, and toxicant can move only from one site to another per time step. Each interior site $(i, j)$ (where $i=2, \ldots, n 1$ and $\mathrm{j}=2, . ., \mathrm{n} 1$ ) has 8 immediate neighbors (i $1, j \mathrm{j})$, (i $1, \mathrm{j}),(\mathrm{i} 1, \mathrm{j}+1),(\mathrm{i}, \mathrm{j} 1),(\mathrm{i}, \mathrm{j}+1),(\mathrm{i}+1, \mathrm{j} 1),(\mathrm{i}+1, \mathrm{j})$, and $(i+1, j+1)$. In order to determine the growth of biofilm from the previous step, we set the following rules:

\subsubsection{States}

- Each site can be occupied by any one of the six possible states: a toxin-producing organism, a toxin-sensitive organism, a nutrient, a toxicant, one toxicant and one nutrient (at the same site), or one toxicant and one toxin-producing organism (at the same site).

\subsubsection{Bacterial growth}

- Cell division occurs in toxin-sensitive (or toxin-producing) organisms with a certain probability (in this case $p=1.0$ ) when their neighboring sites are occupied by at least one nutrient (Fig. 6(a), (b)).

- When more than one toxin-producing (and/or toxin-sensitive) organism compete with one another for a nutrient at the same time, the occupant of the nutrient is determined randomly (i.e., coin toss) (Fig. 6(c), (d), (e)).

\subsubsection{Toxic effect}

-When one or more than one toxin-sensitive organism is present in the immediately- neighboring sites of a toxicant, death of the toxin-sensitive bacteria occurs due to diffusion of the toxicant (Fig. 6(f), (g)).

- When more than one toxicant is present in the neighboring sites of a toxin-sensitive organism, the coin-toss rule is applied to determine which toxicant kills the toxin-sensitive organism (Fig. 6(h)).

- The site of a toxin-producing organism can be shared with a toxicant (Fig. 6(i), (j)). In this case, there is no interaction between the toxicant and the toxinproducing organism.

-When a toxin-producing organism is located in the immediately-neighboring site of a nutrient, the uptake of the nutrient is carried out by the progeny of the toxin-producing organism. A toxicant is immediately produced by the progeny of the toxin-producing organism at one of its neighboring sites (Fig. 7(a)).

- When toxicants and nutrients are located at the neighboring sites of a toxin-sensitive organism, cell division occurs before the toxicants diffuse. Immediately after the reproduction of progeny, the toxicant either diffuses to an empty site (or to the site occupied by a toxin-producing organism) or kills the toxin-sensitive organism (or its "progeny") (Fig. 7(b)).

- When an immediately-neighboring site of a toxinsensitive organism site is shared by a nutrient and a toxicant at the same time, cell division occurs before diffusion of the toxicant (Fig. 7(c)). The simulations are 

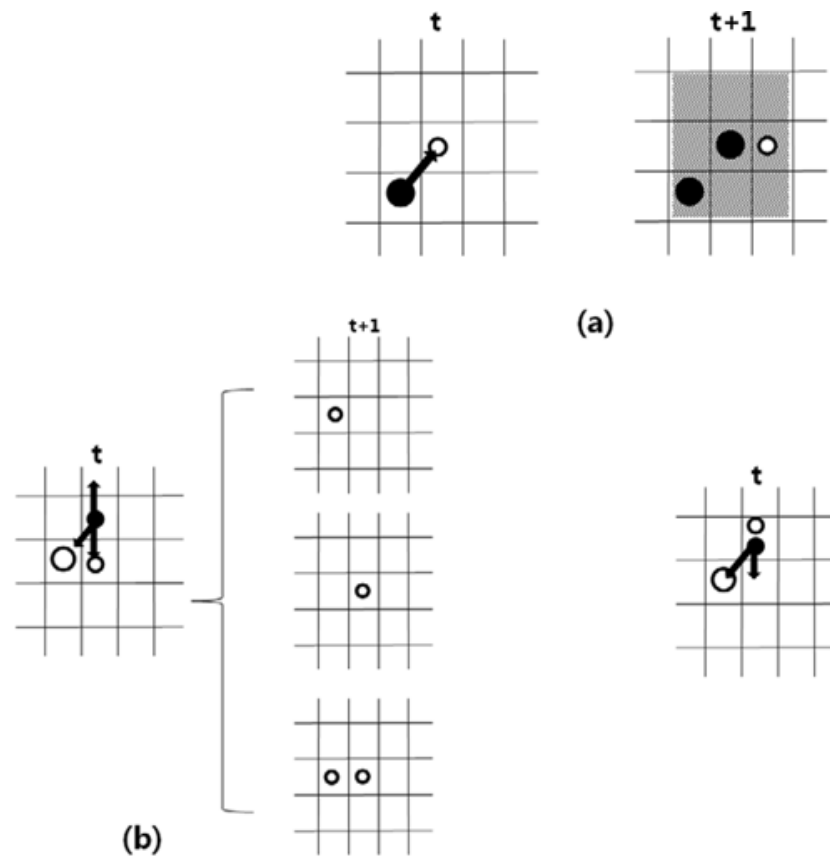

(a)
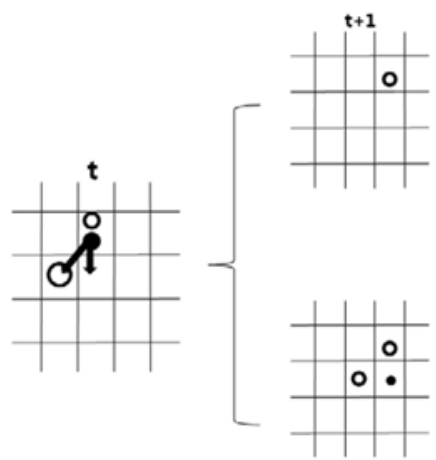

(c)

Fig. 7. Multiplication process of each specimen and occupation of the sites of one of the unoccupied neighbors during one iteration time step $\mathrm{t} \geq \mathrm{t}+1$.
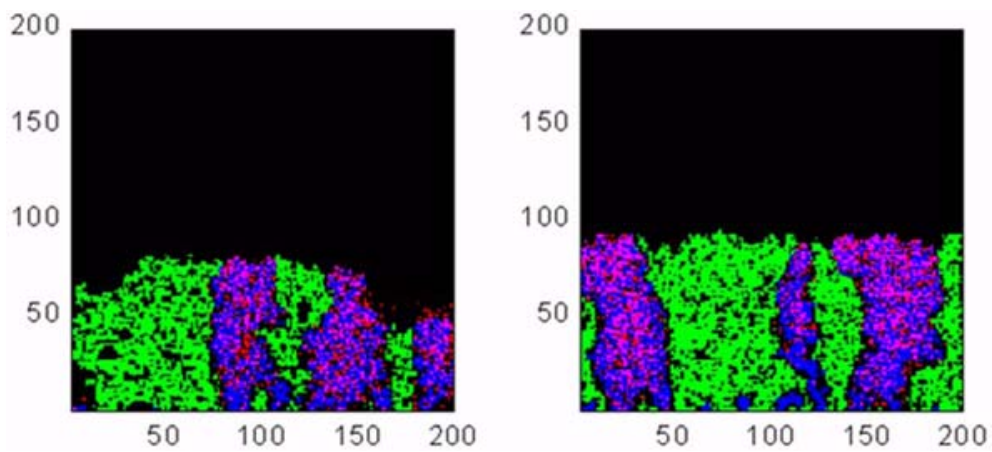

Fig. 8. Typical patterns of biofilm growth. The base was separately inoculated with 20 toxin-sensitive bacteria and 10 toxinproducing bacteria in a repetitive sequence.

performed on an $L=200$ square grid. Nutrients are initially generated based on random distribution. When all of the nutrient particles are consumed, the simulation is over. Periodic boundary conditions are used to minimize the edge effects.

Fig. 8 shows two typical simulated pattern of biofilm growth under the same initial conditions. Before simulation run, ten toxin-sensitive and ten toxin-producing bacteria were randomly distributed. The different initial locations of the bacteria caused different morphological patterns. The green and the blue colors indicate toxinsensitive and toxin-producing bacteria. The red parti- cles represent the toxicants. In the space, the nutrient particles move randomly, but they were not represented in different colors in order to make contrasting colors of the species visually distinct.

\section{DISCUSSION AND SUMMARY}

This paper has introduced three mathematical approaches that could be widely used to construct virtual ecosystems that consist of artificial organisms along with their surroundings, such as landscape. First, a molecular dynamics simulation approach was introduced to build 


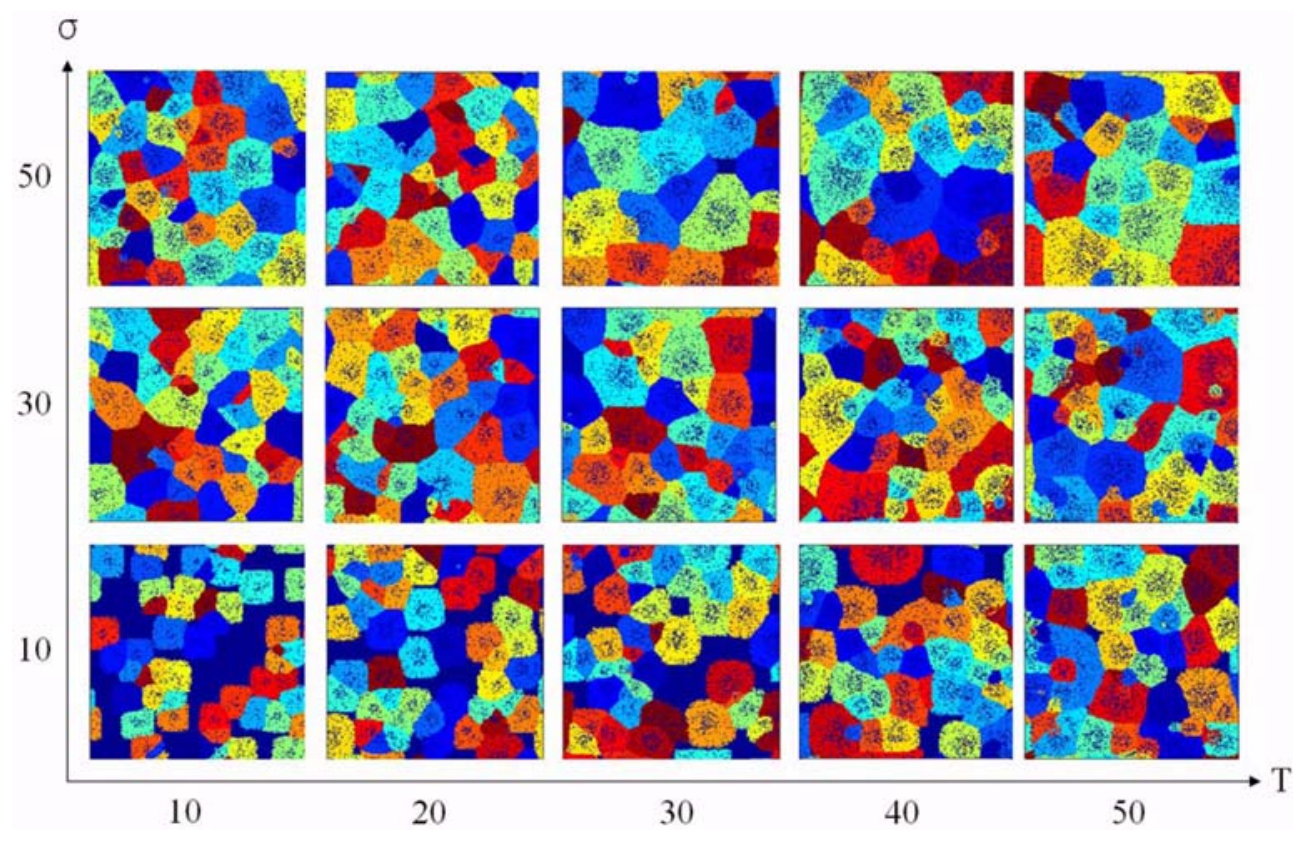

Fig. 9. Typical patterns formed at the steady state $(\mathrm{t}=20)$ for $T=10,20,30,40$, and 50, where $\dot{o}=10,30$, and 50. Each color indicates each territory.

an animal flocking model. Second, a stochastic lattice model approach was applied in order to generate a model of termite territorial dynamics. Lastly, a rulebased cellular automata approach was used in order to construct a biofilm model.

Along with the increase in computational power, virtual ecosystems have attracted considerable attention as a new ecological model that can provide possible explanations for complex and varied ecological phenomena at different levels, from that of individuals to that of an entire community. One of the competitive advantages of a virtual ecosystem is that because it is individual-based, it can easily make connections between lower levels and higher levels, for example, how an environmental disturbance (higher level) influences an individual animal (lower level).

One of the main environmental issues of recent times is that of climate extremes, such as unseasonably high temperatures, caused by global warming (Baes et al., 1977; Emanuel et al., 1980; Gardner et al., 1980; Schlamadinger et al., 1995). Climate change strongly affects both the stability and resilience of an ecosystem (Dukes and Mooney, 1999; Dixon et al., 2003; Mendelsohn et al., 2006). For this reason, many researchers have studied the effects of climate change on ecosystems (Pastor and Post, 1988; Davis, 1990; Bradley et al., 2005; Koneswaran and Nierenberg, 2008). As an example of this, this paper has shown how the model of a termite colony's territory responds to the effects of climate change. In the field, termite colonies grow during the summer and shrink during winter (Messenger and $\mathrm{Su}, 2005)$. In addition, it has been observed that increases in temperature increase the percentage of remaining termite cells (Messenger and $\mathrm{Su}, 2005$ ). Based on these observations, we can assume that climate change can be described in terms of two variables: the period of the summer season, $T$, and the percentage of remaining termite cells, $\sigma$, after shrinkage. By simply introducing the seasonal cycle as a function of $T$ and $\sigma$ into the termite model, we can easily link the phenomena of climate change with the territorial behavior of a termite colony. Fig. 9 shows the typical pattern of 30 termite colony territories at a steady state, which means that the territory formations have changed little after a sufficiently long simulation time.

Overall, the development of virtual ecosystems is important, in that it can provide a foundation for future empirical research on the effects of various environmental factors on natural ecosystems. I am constructing a rice paddy virtual ecosystem on a lattice space in order to explore the effects of climate change on a rice 
paddy ecosystem. This model adopted the stochastic lattice model approach because many variables, describing plants and insects living in a rice paddy, can be relatively easily considered in the approach. I believe that the model can be a powerful tool to predict the stability and the resilience of the ecosystem in response to the environmental change. The study will be appeared elsewhere in the near future.

\section{적 요}

본 논문은 가상 생태계의 개념과 가상생태계를 구현 하는데 중요하게 사용되어 질 수 있는 세 가지 수학 적-물리학적 접근법을 응용 예와 함께 소개 하였다. 가상생태계란 개체기반 모델로써 인공생명체들이 가상 환경하에서 스스로 행동하면서 살아가는 것을 모사하 는 컴퓨터 내에 구현된 생태계를 의미한다. 생물의 무 리행동을 전산 모사하는 분자동역학모사 접근법과, 흰 개미 영토를 전산 모사하는 확률적 격자모델 접근법, 그리고 생물막 성장을 전산 모사하는 규칙기반-세포자 동자모델 접근법을 소개하였다. 실 생태계와의 유사성 을 높이기 위해 가상생태계 모델은 많은 변수들을 사 용하여야 하지만, 기술적인 측면에서 이러한 변수들을 모두 결정하기는 어렵다. 그러나 현재의 눈부신 컴퓨터 성능항상에 힘입어 많은 부분이 극복 되어 지고 있다. 특히, 가상생태계는 기후변화와 같은 환경재앙을 포함 하여 많은 복잡한 생태학적 현상을 개체수준의 낮은 계층에서부터 생물집단 또는 외부 환경수준과 같은 높 은 계층까지를 통합적으로 이해하는데 큰 도움을 줄 수 있을 것이다. 마지막으로 논문에서는 높은 수준의 계층인 기후변화가 낮은 수준의 계층인 개체기반의 흰 개미 생태계에 미치는 복잡한 문제를 어떻게 다룰 수 있는지에 대한 예를 들고 간략하게 논의하였다.

\section{ACKNOWLEDGMENT}

This study was carried out with the support of "Cooperative Research Program for Agricultural Science \& Technology Development (project No. 20100401-030079-001-00-00)", RDA, Republic of Korea.

\section{REFERENCES}

Adioui, M., J. P. Treuil, and O. Arino, 2003: Alignment in a fish school: a mixed Lagrangian-Eulerian approach. Ecological Modelling 167, 19-32.

Adams, R. M., C. Rosenzweig, R. M. Peart, J. T. Ritchie,
B. A. McCarl, J. D. Glyer, R. B. Curry, J. W. Jones, K. J. Boote, and L. H. Allen, 1990: Global Climate Change and U.S. Agriculture. Nature, 345, 219-224.

Baes, C. F., H. E. Goeller, J. S. Olson, and R. M. Rotty, 1977: Carbon dioxide and climate: The uncontrolled experiment. American Scientist 65, 310-320.

Bess, H. A., 1970: Termites of Hawaii and the oceanic islands. In: Krishna, K., Weesner, F.M. (Eds.), Biology of Termites, vol. 2. Academic Press, New York, pp. 448-476.

Bradley, M. J, S. J, Kutz, E. Jenkin, and T. M. O'Hara, 2005: The potential impact of climate change on infectious diseases of Arctic fauna. International Journal of Circumpolar Health 64, 468-477.

Cashing, D. H., and F. R. Harden-Jones, 1968: Why do fish school? Nature 218, 918-920.

Davis, M. B., 1990: Biology and palaeobiology of global climate change: Introduction. Trends in Ecology and Evolution 5, 269-270.

Desai, J. P., J. P. Ostrowski, and V. Kumar, 2002: Modeling and control of formations of nonholonomic mobile robots. IEEE Transaction on Robotics and Automation 17, 905-908.

Dixon, R. K., J. Smith, and S. Guill, 2003: Life on the edge: vulnerability and adaptation of African ecosystems to global climate change. Mitigation and Adaptation Strategies for Global Change 8, 93-113.

Dukes, J. S., and H. Mooney, 1999: Does global change increase the success of biological invaders? Trends in Ecology and Evolution 14, 135-139.

Emanuel, W. R., J. S. Olson, and G. G. Killough, 1980: The expanded use of fossil fuels by the U.S. and the global carbon dioxide problem. Journal of Environmental Management 10, 37-49.

Gardner, R. H., J. B. Mankin, and W. R. Emanuel, 1980: A comparison of three world carbon models. Ecological Modelling 8, 313-332.

Hurtt, G. C., and S. W. Pacala, 1995: The consequences of recruitment limitation: reconciling chance, history, and competitive differences between plants. Journal of Theoretical Biology 176, 1-12.

Huth, A., and C. Wissel, 1994: The simulation of fish schools in comparison with experimental data. Ecological Modelling 75/76, 135-145.

Kane, S., J. M. Reilly, and J. Tobey, 1992: An Empirical Study of the Economic Effects of Climate Change on World Agriculture. Climatic Change, 21, 17-35.

King, E. G., and W. T. Spink, 1975: Development of incipient Formosan subterranean termite colonies in the filed. Annals of the Entomological Society of America 68, 355358.

Koneswaran, G. and D. Nierenberg, 2008: Global farm animal production and global warming: impacting and mitigating climate change. Environmental Health Perspectives 116, 578-582. 
Lee, S.-H., and N.-Y. Su, 2009a: The Influence of branching tunnels on subterranean termites' foraging efficiency: considerations for simulations. Ecological Informatics 4, 152-155.

Lee, S.-H., and N.-Y. Su, 2009b: A Simulation Study of Subterranean Termite's Territory Formation. Ecological Informatics 4, 111-116.

Lee, S.-H., H. K. Pak, and T.-S. Chon, 2004: Criticality in Two Competing Species with Allelopathy based on Cellular Automaton Model. Journal of the Korean Physical Society 44, 651-655.

Lee, S.-H., H. K. Pak, and T.-S. Chon, 2006: Dynamics of Prey-Flock Deformations in Response to Predator's Attack. Journal of theoretical biology 240, 250-259.

Lee, S.-H., N.-Y. Su, and P. Bardunias, 2007: Exploring landscape structure effect on termite territory size using a model approach. Biosystems 90, 890-896.

Li, G. X., Z. R. Dai, D. Z. Zhong, and D. R. Gao, 1979: Integrated control of termites. In: Institute of Zoology, Academica Sinica (Ed.), Integrated Control of Major Insect Pests in China. Science Press, Beijing, pp. 401428 (in Chinese).

Maldonado-Coelho, M., and M. A. Marini, 2004: Mixedspecies bird flocks from Brazilian Atlantic forest: the effects of forest fragmentation and seasonality on their size, richness and stability. Biological Conservation 116, 19-26.

Mendelsohn, R, A. Dinar, and L. Williams, 2006: The distributional impact of climate change on rich and poor countries. Environment and Development Economics 11, 159-178.

Messenger, M. T., and N.-Y. Su, 2005: Colony characteristics and seasonal activity of the Formosan subterranean termite (Isoptera: Rhinotermitidae) in Louis Armstrong Park, New Orleans, Louisiana. Journal of Entomological Sciences 40, 268-279.

Murphy, E. J., P. N. Trathan, J. L. Watkins, K. Reid, M. P. Meredith, J. Forcada, S. E. Thorpe, N. M. Johnston, and P. Rothery, 2007: Climatically driven fluctuations in Southern Ocean ecosystems. Proceeding of the Royal Society Bio- logical Sciences 274, 3057-3067.

Nakamaru, M., 2006: Lattice model in ecology and social sciences. Ecological Research 21, 364-369.

Parrish, J. K., S. V. Viscido, and D. Grunbaum, 2002: Selforganized fish schools: an examination of emergent properties. The Biological Bulletin 202, 296-305.

Pastor, J., and W. M. Post, 1988: Response of northern forests to CO2 -induced climate change. Nature 334, 55-58.

Peacor, S. D., S. Allesina, R. L. Riolo, and T. S. Hunter, 2007: A new computational system, DOVE (Digital Organisms in a Virtual Ecosystem), to study phenotypic plasticity and its effects in food webs. Ecological Modelling, 205, 13-28.

Reynolds, C. W., 1987: Flock, herds, and school: A distributed behavioral model, in computer graphics. SIGGRAPH 87' Conference proceedings 21(4), 25-34

Schlamadinger, B., J. Cushman, and G. Marland, 1995: Biomass Fuels, Energy, Carbon, and Global Climate Change. ORNL Review. 28, 14-21.

Schmidt, K., A. Atkinson, D. Stubing, J. W. McClelland, J. P. Montoya, and M. Voss, 2003: Trophic relationships among Southern Ocean copepods and krill: Some uses and limitations of a stable isotope approach. Limnology and Oceanography 48, 277-289.

Stoodley, P., S. Yang, H. Lappin-Scott, and Z. Lewandowski, 1997: Relationship between mass transfer coefficient and liquid flow velocity in heterogenous biofilms using microelectrodes and confocal microscopy. Biotechnology and Bioengineering 56, 681-688.

Videler, J. J., 1993: Fish Swimming. Chapman \& Hall, London.

Viscido, S. V., M. Millar, and D. S. Wethey, 2001: The response of a selfish herd to an attack from outside the group perimeter. Journal of Theoretical Biology 208, 315-328.

Zheng, M., Y. Kashimori, O. Hoshino, K. Fujita, and T. Kambara, 2005: Behavior pattern (innate action) of individuals in fish schools generating efficient collective evasion from predation. Journal of Theoretical Biology 235, 153-167. 